\title{
Microgenesis of the Deterministic Influence of Pupils' Frustrated Need for Success Depending on Their Academic Achievements
}

\section{Дослідження мікроґенези детермінантного впливу фрустрації потреби досягнення успіху в школярів із різними навчальними досягненнями}

\author{
Nataliia Musiiaka \\ Ph.D. in Psychology, Senior \\ Researcher, Doctoral Student
}

\author{
Наталія Мусіяка \\ кандидат психологічних \\ наук, старший науковий \\ співробітник, докторант
}

\begin{abstract}
E-mail:natamail0870@gmail.com orcid.org/0000-0002-4439-7965

Researcher ID: D-8001-2019
\end{abstract}
Kostiuk Institute of Psychology Iнститут психологї імені of the National Academy of Educational Sciences of Ukraine, Kyiv, Ukraine 2, Pankivska street, Kyiv, 01033
Г. С. Костюка НАПН України, м. Київ, Украӥна вул. Панківська, 2, м. Київ, 01033

Original manuscript received February 28, 2019

Revised manuscript accepted March 25, 2019

\section{ABSTRACT}

The article presents the experimental study of the frustrated need for success and the peculiarities of its manifestation as a personal determinant of educational achievement characteristic for elementary and secondary school pupils. The article compares pupils' frustration with their need to success achievement at different stages of education and describes its microgenesis. Both identical and heteropolar tendencies in the frustration development have 
been determined for the groups of pupils with different levels of educational achievements. As for elementary school pupils with excellent and average results, there is a certain destabilization of their personal status, which is evidenced by the significant rise of frustration in absence of a success; this is a reflection of the difficulties that accompany subjective incorporation into the study process of some pupils form this group. As for elementary school pupils with poor results, here is the opposite trend. Such people show mainly the normal level of frustration, which indicates blocking of personal potentials in terms of the need for success. It has been experimentally determined that the adaptive period of the fifth grade pupils to study at the secondary school has clear signs of aggravated frustration with the need to succeed at pupils with low educational achievements. Thus, there is an unfavourable psychological background with built-up factors hindering personal potencies for success achievement and overall productivity during learning of such pupils. The architecture of the frustration with the need to success achievement shows the existing microgenetic tendencies, which determinate pupils' achievements on the ontogenetic plane. The determined peculiarities of the frustrated need to success as a process and its destructive potential require development of a system of corrective and developmental influences in order to ease the destructive frustrated state and to provide productive psychological support for the pupils' personal development in the educational environment.

Key words: genesis, microgenesis, educational achievements, personal determinants, personality of a pupil, need for success, frustration.

\section{Вступ}

Реформування сучасного вітчизняного освітнього простору в ранг пріоритетної ставить проблему становлення особистості, здатної до ефективного саморозвитку й успішної самореалізації. Формування компетентностей, «потрібних дитині для успішної самореалізації в суспільстві», є одним із ключових завдань Концепції нової української школи (Нова Українська Школа, 2017: 11). Компетентнісний підхід передбачає «зміщення акцентів із накопичення нормативно визначених знань, умінь і навичок на вироблення і розвиток умінь діяти, застосовувати досвід у проблемних умовах... Саме тоді створюються умови для включення механізмів компетентності - здатності діяти 
в конкретних умовах і мотивів досягти результату» (Нова Українська Школа, 2017: 12).

Аналізуючи особистісне зростання дитини в умовах сучасної освітньої системи, С. Д. Максименко підкреслює важливість парадигми особистісної успішності дитини у навчанні та їі прогнозування. Перехід від школи як моноінституційної освітньої організації до поліорганізаційного бачення шляхів включення зростаючої особистості до освітнього простору актуалізує проблему особистісної ефективності, особистісної результативності школяра як суб'єкта навчальної діяльності та його здатності бути успішним. У зв’язку з цим, зазначає учений, гостро постає «питання про те, чи зможе дитина навчатися в тій чи іншій школі, й наскільки вона буде успішною» (Максименко, 2008: 12).

Особливо значущим у цьому сенсі є молодший шкільний вік, оскільки саме на першому етапі включення дитини у шкільний простір - у початковій школі - відбувається зародження конструктивного чи деструктивного становлення особистісного статусу школяра як суб’єкта учіння.

При цьому особливої ваги, як підкреслював Г. С. Костюк, набуває розгляд цієї проблеми у дихотомії «результативність навчальної діяльності - особистісний розвиток», оскільки успіх або неуспіх школяра у процесі навчання зумовлює значний вплив на становлення його особистості (Костюк, 1989).

У сучасній вітчизняній психології дослідження проблеми результативності навчальної діяльності та їі детермінації зосереджено на розкритті: особистісної ефективності школяра у контексті концепції психічного розвитку Г. С. Костюка (Дригус, 2016); проблеми рефлексії як одного з психологічних механізмів становлення особистісної ефективності школяра (Яворська-Вєтрова, 2018); розвитку творчого мислення як особистісної детермінанти навчальних досягнень молодших школярів (Мусіяка, 2018); специфіки ставлення до навчання у встигаючих і невстигаючих студентів із домінуванням різних видів мотивації 
досягнення (Козуб, 2016); проблеми первинної шкільної неуспішності та її психологічних механізмів (Кондратенко, 2018); диференційованого впливу особистісних чинників залежно від етапу онтогенезу (Онуфрієва \& Ващенко, 2018). У колективній монографії «Становлення особистості школярів з різними навчальними досягненнями в онтогенетичному просторі (2013) висвітлено особливості становлення самосвідомості (Яворська-Вєтрова, 2013), емоційної сфери (Мусіяка, 2013), регулятивної сфери (Петренко, 2013) школярів із різним рівнем навчальних досягнень.

У сучасній зарубіжній психології проблема особистісної детермінації навчальних досягнень розкрита у таких спектрах: досліджено зв'язок між навчальними досягненнями, самоефективністю та мотивацією навчальної діяльності; зроблено висновок, що провідними детермінантами навчальної успішності школярів середньої та старшої школи є академічна (навчальна) самоефективність, емоційна самоефективність і мотивація (Doğan, 2015), водночас у студентів коледжів зафіксовано взаємозв' язок навчальних досягнень лише з мотиваційною детермінантою (Meens, Bakx, Klimstra \& Denissen, 2018). Дослідниками Iniesta, López-López, Corbíl, Pérez \& Costa (2017) акцентовано увагу на значному впливі когнітивних і мотиваційних змінних і стратегій навчання на прогнозування рівня навчальних досягнень у старшокласників.

Motlagh, Amrai, Yazdani, Abderahim \& Souri (2011) установили, що самоефективність, самооцінка та саморегуляція є детермінантами навчальних досягнень учнів середньої школи. Дослідження взаємозв'язку між самооцінкою, інтелектом і навчальними досягненнями виявило статистично значущий зв'язок між інтелектом і навчальними досягненнями, а також відсутність зв'язку між самооцінкою та інтелектом. Водночас не зафіксовано статистично значущого взаємозв'язку між самооцінкою та навчальними досягненнями школярів (Kaya \& Oğurlu, 2015). Дослідниками Steinmayr, Crede, McElvany \& Wirthwein (2016) уста- 
новлено деструктивний вплив тривожності на навчальні досягнення підлітків.

Окремі психологічні розвідки присвячено вивченню впливу на рівень навчальних досягнень школярів і студентів використання у навчальній діяльності сучасних медіа- та цифрових технологій. Так, дослідники Beetham \& Sharpe (2013) указують на те, що цифрові технології сприяють продуктивності навчальної діяльності та підвищенню рівня навчальних досягнень. Інші дослідження мають амбівалентні результати, що вказують на деструктивний вплив цифрових технологій на рівень навчальних досягнень молодших і старших школярів. Констатовано, що вони можуть відволікати або навіть руйнувати академічну спрямованість їх навчальної діяльності (Salomon \& Ben-David Kolikant, 2016). Дослідники Lepp, Barkley \& Karpinski (2015) зафіксували тісний зв'язок між використанням мобільних телефонів і текстових повідомлень зі зниженням рівня навчальних досягнень учнів коледжів.

Зазначимо, що у контексті предмета нашого дослідження - особистісної детермінації навчальних досягнень ключовим є такий їі структурний компонент, як потреба школяра у досягненні успіху. В статті репрезентовано результати дослідження дихотомічної проекції, а саме - фрустрації потреби досягнення успіху в учнів із різними навчальними досягненнями.

Мета статті - здійснити аналіз детермінантного впливу фрустрації потреби досягнення успіху в школярів із різним рівнем навчальних досягнень.

\section{Завдання статті}

1. 3' ясувати особливості рівневої констеляції фрустрації потреби досягнення успіху в учнів із різними навчальними досягненнями на певному етапі навчання.

2. Простежити мікроґенезу та встановити мікрогенетичні тенденції становлення фрустрації потреби досягнен- 
ня успіху в учнів початкової та основної школи з різними навчальними досягненнями.

\section{Методи та методики дослідження}

Із метою дослідження фрустрації потреби досягнення успіху було використано «Тест шкільної тривожності Філліпса» (Головей, 2002). Характеризуючи проблему суб’єктності учіння, М. В. Папуча акцентує увагу на тому, що мотив досягнення успіху «може існувати в двох протилежних за значенням для особистості формах» (Папуча, 2008). Перша з них має назву «прагнення успіху», а друга - «страх невдачі», що супроводжує фрустрацію потреби досягнення успіху.

Фрустрація потреби досягнення успіху характеризується як «несприятливе психічне тло, що не дозволяє дитині розвивати свої власні потреби в успіху, досягненні високого результату» (Головей, 2002: 326). Рівні фрустрації потреби досягнення успіху відповідно до змістового наповнення були такі: I рівень - занижений; II - нормальний; III - підвищений; IV - високий рівень прояву фрустрації потреби досягнення успіху (Головей, 2002). Залежно від результативності навчальної діяльності школярі були розподілені на три групи: перша група - учні з високим рівнем навчальних досягнень, друга - з посереднім і третя група 3 низьким рівнем навчальних досягнень. Дослідження проводилося з учнями третіх і четвертих класів початкової школи й учнями п'ятих і шостих класів основної школи. Вибірку досліджуваних склали 224 учні. У процесі аналізу експериментального матеріалу було застосовано відповідні методи математичної статистики, зокрема критерій $\varphi *-$ кутове перетворення Фішера.

\section{Результати та дискусії}

Перейдемо до розгляду рівневої характеристики фрустрації потреби досягнення успіху й особливостей її прояву в школярів із різним рівнем навчальних досягнень на пев- 
ному етапі навчання у початковій та основній школі (від третього до шостого класу), а також з'ясуємо мікрогенетичні тенденції становлення фрустрації потреби досягнення успіху в школярів.

Аналіз рівневої констеляції фрустрації потреби досягнення успіху учнів із різним рівнем навчальних досягнень упродовж їх навчання у третьому класі початкової школи дав змогу з'ясувати такі її особливості у мікрогенетичній площині (рис. 1).

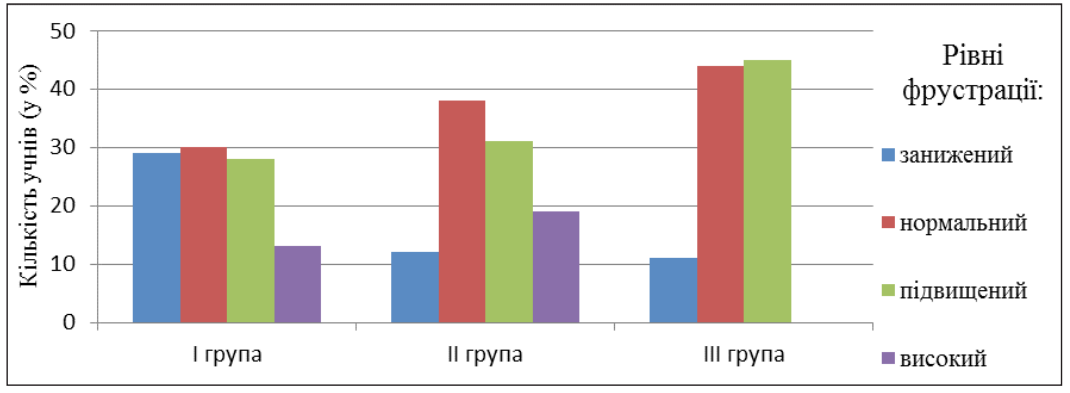

Puc. 1. Структура фрустрації потреби досягнення успіху в третьокласників із різним рівнем навчальних досягнень

У третьокласників із високим рівнем навчальних досягнень зафіксовано наявність усіх рівнів фрустрації потреби досягнення успіху. I рангове місце поділяють як нормальний, так і підвищений і занижений рівні фрустрації потреби досягнення успіху - 30\%, 28\% і 29\% відповідно. II рангове місце в цій групі посідає високий рівень фрустрації потреби досягнення успіху, хоча кількісно він властивий 13\% третьокласників (рис. 1).

У школярів третього класу з посереднім рівнем навчальних досягнень на I ранговому місці зафіксовано нормальний рівень фрустрації потреби досягнення успіху (38\%), на II ранговому місці - підвищений рівень (31\%), на III ранговому місці - високий (19\%), а на IV ранговому місці - занижений рівень (12\% ) фрустрації потреби досягнення успіху. 
У третьокласників із низьким рівнем навчальних досягнень I рангове місце поділяють нормальний і підвищений рівні фрустрації. II рангове місце посідає занижений рівень фрустрації потреби досягнення успіху. Привертає увагу те, що в цій групі відсутній високий рівень фрустрації потреби досягнення успіху.

Порівняльний аналіз третьокласників із різним рівнем навчальних досягнень розкрив суттєві відмінності фрустрації потреби досягнення успіху (рис. 2).

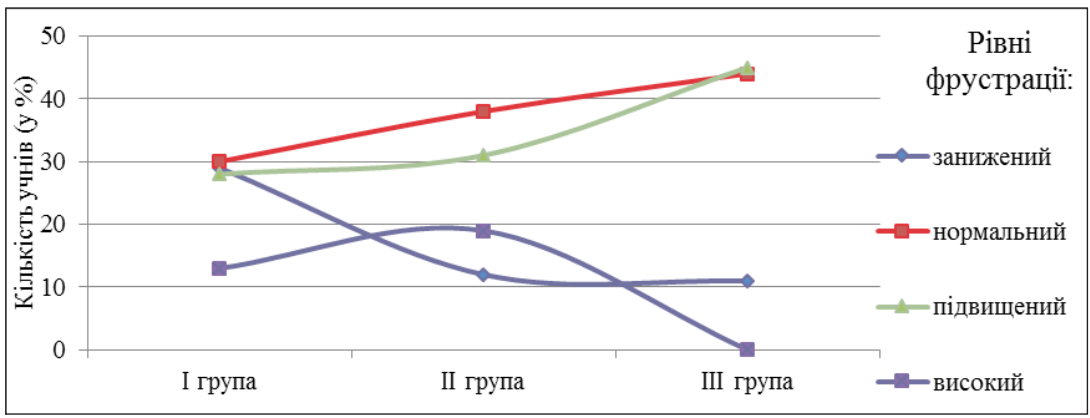

Puc. 2. Мікрогенеза структури фрустрації потреби досягнення успіху в третьокласників із різним рівнем навчальних досягнень

Так, якщо високий рівень фрустрації потреби досягнення успіху відмінно встигаючих школярів був репрезентований у $13 \%$ учнів, то у слабко встигаючих він відсутній зовсім. Крім того, порівняння показників полярних груп свідчить, що зріс відсоток третьокласників, яким притаманний підвищений рівень: від 28\% у відмінно встигаючих учнів до $45 \%$ у слабко встигаючих школярів. Зростає також нормальний рівень фрустрації потреби досягнення успіху: якщо в групі відмінно встигаючих він був зафіксований у третини учнів, то в групі слабко встигаючих - у майже половини школярів цієї групи (30\% і 44\% відповідно). Занижений рівень фрустрації потреби досягнення успіху в групах школярів із полярним рівнем навчальних 
досягнень зменшується майзже втричі: 3 29\% у відмінно встигаючих до $11 \%$ у слабко встигаючих третьокласників. Також простежується його кількісна міграція у бік стрімкого зниження на рівні статистичної значущості $(\varphi *=2,31$ при $p \leq 0,01)$.

Порівняльний аналіз мікрогенези рівневої констеляції фрустрації потреби досягнення успіху третьокласників засвідчує як тотожність, так і різнополярність тенденцій перебігу фрустрації у групах школярів із різним рівнем навчальних досягнень. Прикметною рисою потреби досягнення успіху у відмінно встигаючих третьокласників є ознаки певної дестабілізації особистісного статусу школяра, про що свідчить наявність у 41 \% школярів цієї групи підвищеного і високого рівнів фрустрації потреби. Тотожність профілю з цією тенденцією зафіксовано також і в посередньо встигаючих третьокласників, у яких синтез підвищеного і високого рівня фрустрації потреби досягнення успіху властивий 50\% школярів цієї групи. Це є віддзеркаленням тих труднощів, що супроводжують процес суб'єктного включення частини школярів цих груп до процесу учіння. Протилежна тенденція на мікрорівні зафіксована у третьокласників із низьким рівнем навчальних досягнень. У школярів цієї групи відсутній високий рівень фрустрації потреби досягнення успіху, а наявність нормального рівня у 44\% (наполовину більше, ніж у третьокласників із високим рівнем навчальних досягнень) блокує спонукальні інтенції школярів до самовдосконалення.

Аналіз особливостей фрустрації потреби досягнення успіху четвертокласників із різним рівнем навчальних досягнень представлено на рис. 3.

Отримані експериментальні дані свідчать, що у відмінно встигаючих четвертокласників на I ранговому місці перебуває підвищений рівень фрустрації потреби досягнення успіху в 66\% учнів. II рангове місце у структурі фрустрації посідають нормальний і занижений рівні, виявлені у $16 \%$ 
і 18\% школярів цієї групи відповідно; високий рівень фрустрації у школярів цієї групи відсутній. Привертає увагу те, що в четвертокласників із високим рівнем навчальних досягнень підвищений рівень фрустрації потреби досягнення успіху в чотири рази перевищує нормальний рівень (66\% і 16\% відповідно). Це свідчить про складнощі становлення потребової сфери досягнення успіху в школярів цієї групи.

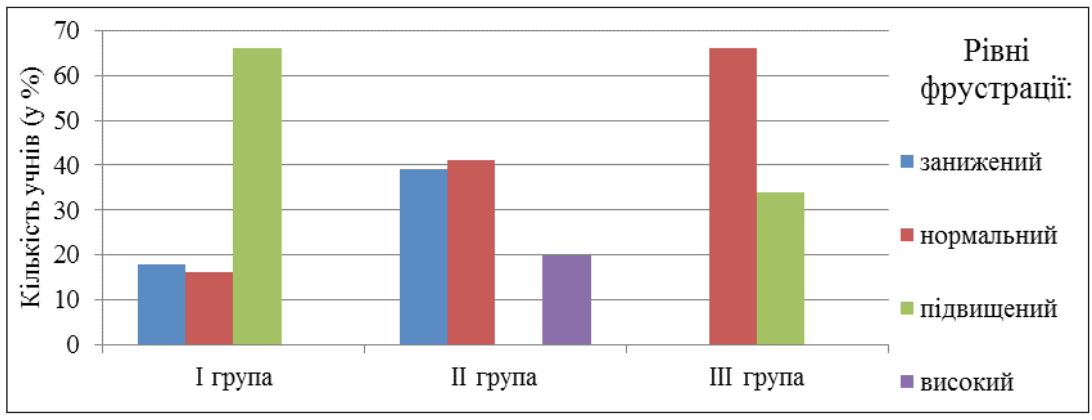

Puc. 3. Структура фрустрації потреби досягнення успіху в четвертокласників із різним рівнем навчальних досягнень

У структурі фрустрації потреби досягнення успіху четвертокласників із посереднім рівнем навчальних досягнень I рангове місце поділяють нормальний і занижений рівні фрустрації (39\% і 41\% відповідно), зростання яких, порівняно з першою групою (більше ніж у два рази), зафіксовано на статистично значущому рівні $(\varphi *=1,87$ при $p \leq 0,05)$. II рангове місце посідає високий рівень фрустрації потреби досягнення успіху, який притаманний 1/5 школярів.

У слабко встигаючих четвертокласників стрімко зростає (на статистично значущому рівні: $\varphi^{*}=2,79$ при $p \leq 0,01$ ) нормальний рівень фрустрації потреби досягнення успіху, який займає I рангове місце $(66 \%)$. Але третина школярів (34\%) має підвищений рівень фрустрації потреби досягнення успіху (II рангове місце). У школярів цієї групи відсутній як занижений, так і високий рівні фрустрації по- 
треби досягнення успіху. Значний розрив між нормальним і підвищеним рівнями (майже удвічі - 66\% і $34 \%$ відповідно) не впливає на спонукальну здатність до підвищення власних навчальних досягнень у школярів із низьким рівнем навчальних досягнень.

Порівняльний аналіз даних виявив суттєві відмінності у структурі фрустрації потреби досягнення успіху в школярів із різним рівнем навчальних досягнень на цьому етапі навчання (рис. 4).

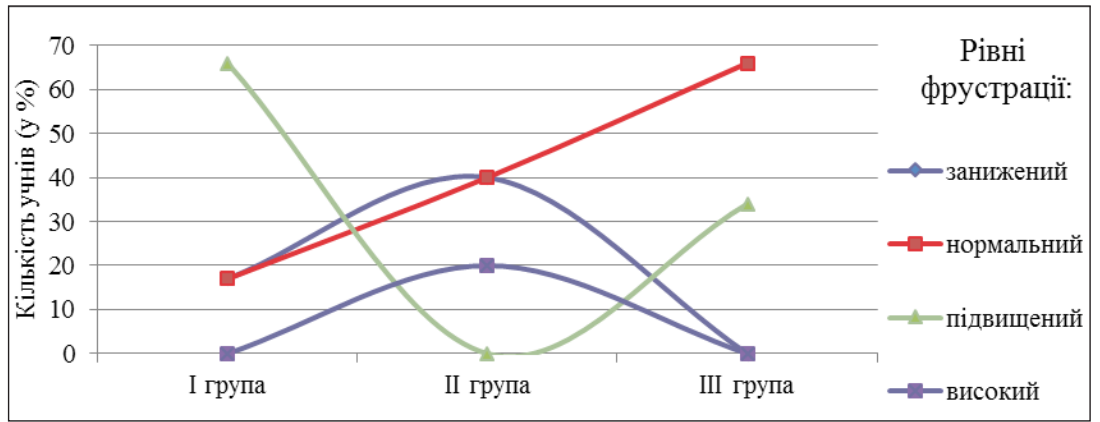

Puc. 4. Мікрогенеза структури фрустрації потреби досягнення успіху в четвертокласників із різним рівнем навчальних досягнень

У четвертокласників із різним рівнем навчальних досягнень чітко виявлено гетерохронний характер рівневої констеляції фрустрації потреби досягнення успіху. Серед різновекторності мікрогенетичних тенденцій у четвертокласників виокремлюються такі домінантні лінії.

Від I до III групи відбувається зростання (у чотири рази) нормального рівня. Водночас простежується зниження (удвічі) підвищеного рівня фрустрації потреби досягнення успіху на статистично значущому рівні $(\varphi *=1,68$ при $p \leq 0,01)$. I хоча високий рівень фрустрації потреби досягнення успіху ні у відмінно встигаючих, ні у слабковстигаючих четвертокласників не було зафіксовано, співвідношення між нормальним і підвищеним рівнями у групах 
учнів із високим і низьким рівнями навчальних досягнень є індикатором, з одного боку, значного зростання фрустрації потреби досягнення успіху у відмінно встигаючих школярів, а з іншого - у школярів із низьким рівнем навчальних досягнень - блокування особистісних потенцій щодо потреби досягнення успіху i, як наслідок, низьких навчальних досягнень.

Отримані експериментальні дані щодо особливостей перебігу фрустрації потреби досягнення успіху в четвертокласників із різним рівнем навчальних досягнень вимагають особливої уваги до проведення діагностичної та корекційної роботи на цьому етапі навчання у початковій школі.

Наступний етап дослідження полягав у з'ясуванні особливостей фрустрації потреби досягнення успіху в школярів основної школи - учнів п'ятого та шостого класів із різним рівнем навчальних досягнень.

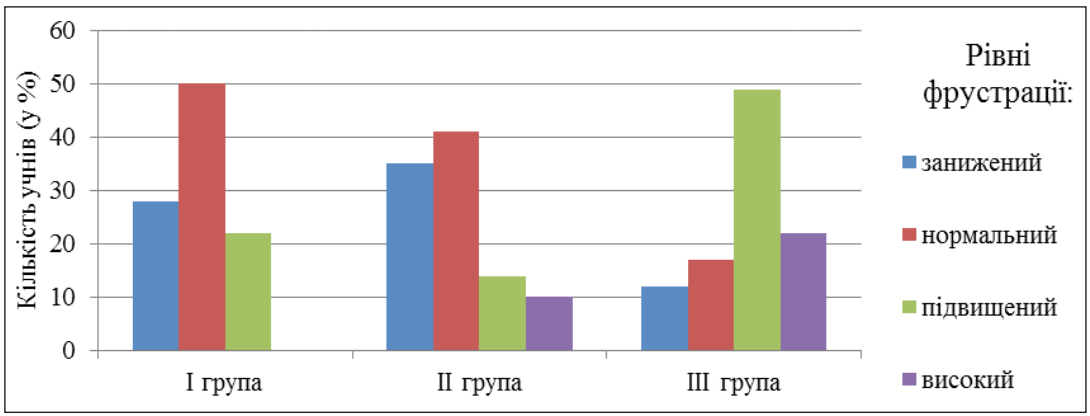

Puc. 5. Структура фрустрації потреби досягнення успіху в п'ятикласників із різним рівнем навчальних досягнень

У п'ятикласників із високим рівнем навчальних досягнень зафіксовано таку рівневу констеляцію фрустрації потреби досягнення успіху: на I ранговому місці - нормальний рівень фрустрації (50\%); на II ранговому місці занижений рівень (28\%); на III ранговому місці - підвищений рівень фрустрації (22\%) (рис. 5). Високий рівень у школярів цієї групи відсутній. У посередньо встигаючих 
п’ятикласників рівнева констеляція фрустрації потреби досягнення успіху така: I рангове місце посідає нормальний рівень, II рангове місце - занижений, III рангове місце - підвищений і IV рангове місце - високий рівень фрустрації (41\%, 35\%, 14\% і 10\% відповідно).

У слабко встигаючих п'ятикласників установлено таку рівневу констеляцію: у цій групі I рангове місце посідає підвищений рівень фрустрації потреби досягнення успіху (майже у половини школярів цієї групи - 49\% ); на II ранговому місці - високий рівень (22\% ); на III ранговому місці зафіксовано нормальний рівень фрустрації (17\% ); занижений рівень фрустрації (12\% ) посідає IV рангове місце.

Домінантність підвищеного та високого рівнів фрустрації потреби досягнення успіху в $3 / 4$ слабко встигаючих п'ятикласників свідчить про наявність несприятливого підгрунтя для активізації особистісних потенцій і є ознакою прояву деструкції становлення особистісної ефективності п'ятикласників цієї групи.

Порівняльний аналіз показників різних за рівнем навчальних досягнень груп п'ятикласників дав змогу визначити такі особливості фрустрації потреби досягнення успіху в цих учнів (рис. 6).

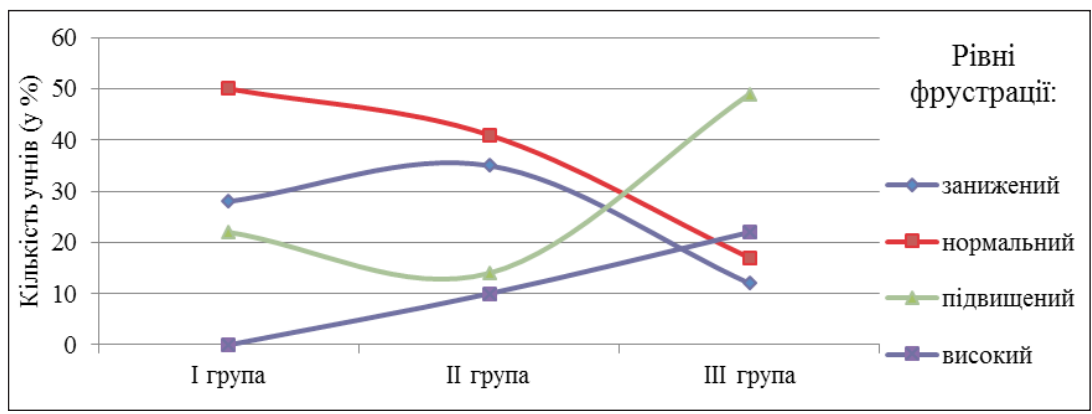

Puc. 6. Мікрогенеза структури фрустрації потреби досягнення успіху в п'ятикласників із різним рівнем навчальних досягнень 
Адаптивний період учнів п'ятого класу до навчання в основній школі має чіткі ознаки деструкції потреби досягнення успіху в школярів із низьким рівнем навчальних досягнень. I якщо профілі рівневої констеляції потреби досягнення успіху п'ятикласників із високим і посереднім рівнями навчальних досягнень майже тотожні та мають кількісну статистично незначущу відмінність між цими групами, то в слабко встигаючих п'ятикласників абрис профілю змінюється.

Порівняльний аналіз експериментальних даних груп п'ятикласників з високим і низьким рівнями навчальних досягнень показує, що у мікрогенезі стрижневим є різке, статистично значуще ( $\varphi *=1,73$ при $p \leq 0,05)$ зниження нормального рівня майже втричі (з 50\% до 17\% відповідно). При цьому зафіксовано статистично значуще $(\varphi *=1,66$ при $p \leq 0,05$ ) зростання більш ніж удвічі (з $22 \%$ до $49 \%$ відповідно) підвищеного рівня. Водночас у $1 / 5$ п'ятикласників із низьким рівнем навчальних досягнень з'являється IV piвень фрустрації - високий, який був відсутній у школярів із високим рівнем навчальних досягнень. Отже, синтез підвищеного і високого рівнів фрустрації потреби досягнення успіху притаманний $2 / 3$ школярів із низьким рівнем навчальних досягнень (71\%). Це є індикатором того, що саме у цій групі є найбільші ризики щодо дестабілізації процесу становлення особистісної ефективності, яка ускладнюється супровідним адаптаційним періодом до навчання школяра в основній школі. Наведені вище дані щодо рівня фрустрації потреби досягнення успіху в п'ятикласників свідчать про необхідність своєчасного включення диференційованих стратегій у процес навчально-виховної взаємодії.

Аналіз особливостей рівневої констеляції фрустрації потреби досягнення успіху в шестикласників із різним рівнем навчальних досягнень свідчить про таку її структурну організацію (рис. 7). 


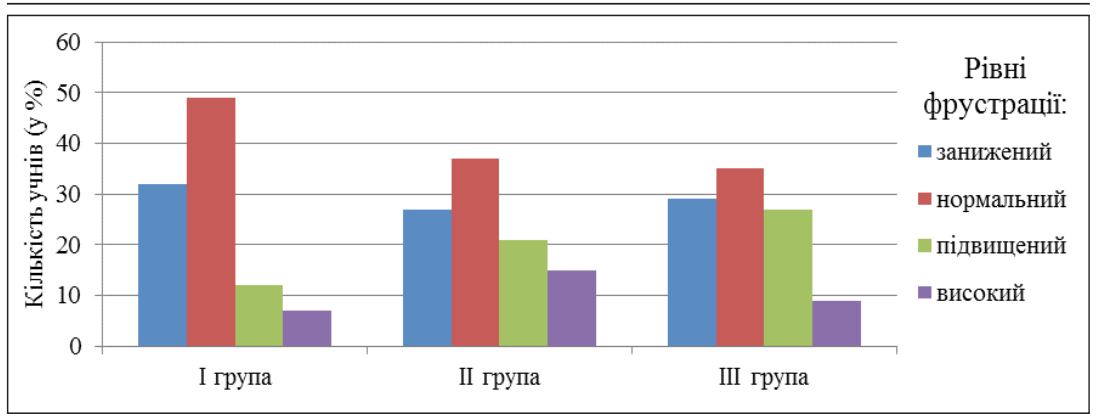

Puc. 7. Структура фрустрації потреби досягнення успіху в шестикласників із різним рівнем навчальних досягнень

У відмінно встигаючих шестикласників I рангове місце посідає нормальний рівень фрустрації, що притаманний майже половині школярів цієї групи; II рангове місце - занижений рівень, зафіксований у третини школярів (32\%); III рангове місце - підвищений рівень фрустрації потреби досягнення успіху (12\%), IV рангове місце - високий рівень (7\%).

Отже, у шестикласників із високим рівнем навчальних досягнень потреба досягнення успіху має продуктивний статус свого перебігу. Синтез підвищеного і високого рівнів фрустрації становить у цій групі 19\%. Лише в 1/5 школярів фрустрація потреби досягнення успіху має несприятливу мікрогенетичну тенденцію.

У посередньо встигаючих шестикласників ранговий статус рівневої структури потреби досягнення успіху схожий із попередньою групою, відрізняючись лише в кількісній репрезентації. Так, від I до II групи спостерігається зниження низького та заниженого рівнів фрустрації потреби досягнення успіху (до $37 \%$ і 27\% відповідно), проте вони не поступаються домінантним місцем - посідають відповідно I та II рангові місця. Одночасно зафіксовано зростання від I до II групи підвищеного рівня фрустрації потреби досягнення успіху (до 21 \% школярів), що відповідає III 
ранговому місцю, а також високого її рівня до $15 \%$, який займає IV рангове місце.

У слабко встигаючих шестикласників нормальний рівень посів I рангове місце, занижений і підвищений рівні поділяють II та III рангові місця, а високий рівень - на IV ранговому місці. Підвищений і високий рівні фрустрації у своїй єдності становлять $36 \%$ і кількісно тотожні групі школярів із середнім рівнем навчальних досягнень.

Аналіз мікрогенетичних тенденцій фрустрації досягнення успіху в шестикласників із різним рівнем навчальних досягнень показав, що генералізованою особливістю є ідентичність рангової супідрядності рівнів фрустрації у школярів як високого, так середнього і низького рівнів навчальних досягнень (рис. 8).

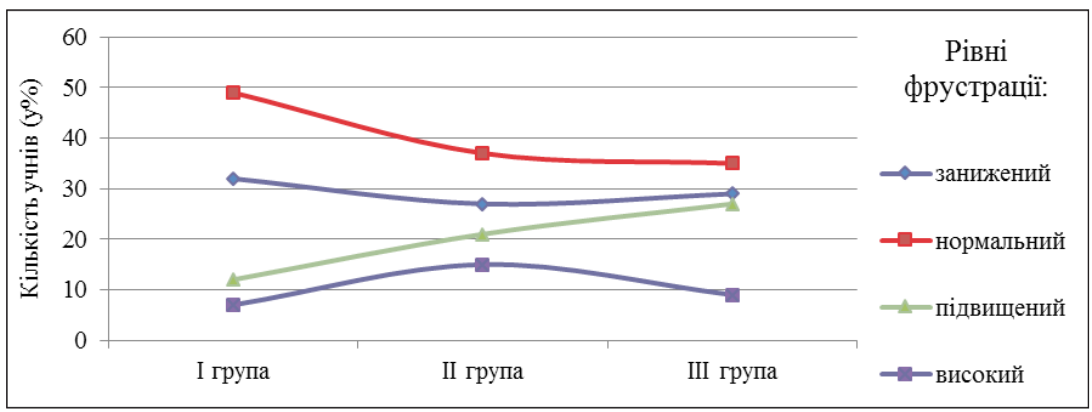

Puc. 8. Мікроґенеза структури фрустрації потреби досягнення успіху в шестикласників із різним рівнем навчальних досягнень

Водночас порівняння полярних груп - I та III - засвідчує зниження нормального рівня фрустрації (з 49\% до 35\% відповідно) і зростання її підвищеного рівня (з 12\% до $27 \%$ відповідно); зафіксовано також зростання - з 19\% до $36 \%$ - у синтезі підвищеного і високого рівнів фрустрації потреби досягнення успіху в шестикласників із високим і низьким рівнями навчальних досягнень. 3 огляду на ці дані постає проблема необхідності простеження динаміки 
фрустрації потреби досягнення успіху на наступних етапах навчання учнів підліткового та старшого шкільного віку.

\section{Висновки}

Отже, отримані експериментальні дані переконливо свідчать про наявність у архітектоніці фрустрації потреби досягнення успіху мікрогенетичних тенденцій, що репрезентують детермінацію навчальних досягнень школяра в онтогенетичному вимірі. Порівняльний аналіз мікрогенези рівневої констеляції фрустрації потреби досягнення успіху третьокласників засвідчує як тотожність, так і різнополярність тенденцій перебігу фрустрації у групах школярів із різним рівнем навчальних досягнень. Прикметною рисою потреби досягнення успіху у відмінно встигаючих і посередньо встигаючих молодших школярів є ознаки певної дестабілізації особистісного статусу школяра, про що свідчить значне зростання фрустрації потреби досягнення успіху, i є віддзеркаленням тих труднощів, які супроводжують процес суб'єктного включення частини школярів цих груп до процесу учіння. Протилежна тенденція на мікрорівні зафіксована у слабко встигаючих молодших школярів - домінування нормального рівня є індикатором блокування особистісних потенцій щодо потреби досягнення успіху i, як наслідок, низького рівня навчальних досягнень.

Адаптивний період учнів п'ятого класу до навчання в основній школі має чіткі ознаки деструкції фрустрації потреби досягнення успіху в школярів із низьким рівнем навчальних досягнень. Аналіз мікрогенетичних тенденцій фрустрації досягнення успіху в шестикласників із різним рівнем навчальних досягнень показав, що генералізованою особливістю є ідентичність рангової супідрядності рівнів фрустрації у школярів як високого, так середнього і низького рівнів навчальних досягнень. 3 огляду на ці дані постає проблема необхідності простеження динаміки фрустрації потреби досягнення успіху на наступних етапах навчання учнів підліткового та старшого шкільного віку. 
Установлені особливості фрустрації потреби досягнення успіху та її деструкції вимагають розробки системи корекційно-розвивальних впливів із метою нівелювання деструктивного стану фрустрації та забезпечення продуктивного психологічного супроводу особистісного розвитку школяра в освітньому середовищі.

Перспективи подальших досліджень передбачатимуть з'ясування макрогенетичних тенденції становлення фрустрації потреби досягнення успіху в учнів із різними навчальними досягненнями на певних етапах онтогенезу.

\section{Література}

Ващенко І. В., Онуфрієва Л. А. Концептуальні межі поняття копінгстратегій особистості у психології. Проблеми сучасної психологї̈: Збірник наукових пращь Кам'янець-Подільського національного університету імені Івана Огієнка, Інституту психології ілені Г. С. Костюка НАПН Украйни. Кам'янець-Подільський : Аксіома, 2018. Вип. 41. С. 228-239. DOI 10.32626/2227-6246.2018$41.228-239$.

Дригус М. Т. Проблема особистісної ефективності у контексті наукової спадщини Г. С. Костюка. Проблеми сучасної психологї: Збірник наукових праць Кам'янеиь-Подільського національного університету ілені Івана Огієнка, Інституту психології імені Г. С. Костюка НАПН України. Кам'янець-Подільський : Аксіома, 2016. Вип. 33. С. 148-161.

Козуб Я. В. Специфіка ставлення до навчання у встигаючих та невстигаючих студентів з домінуванням різних видів мотивації досягнення. Проблеми сучасної психологї: Збірник наукових пращь Кам'янещь-Подільського національного університету імені Івана Огієнка, Інституту психологї̈ імені Г. С. Костюка НАПН України. Кам'янець-Подільський : Аксіома, 2016. Вип. 32. С. 218234.

Кондратенко Л. О. Проблеми первинної шкільної неуспішності в історії вітчизняної психології: автореф. дис. ... д-ра психол. наук: 19.00.01. Київ, 2018. 43 с.

Костюк Г. С. Навчально-виховний процес і психічний розвиток особистості / за ред. Л. М. Проколієнко. Київ : Радянська школа, 1989. $608 \mathrm{c}$.

Максименко С. Д. та ін. Особистість: прогноз розвитку і життєвий шлях. Психологічне опосередкування педагогічних впливів на розвиток особистісної активності в освітньому просторі: метод. реком. / 
Інститут психології ім. Г. С. Костюка АПН України. Київ : ДП «Інформаційно-аналітичне агентство», 2008. С. 4-35.

Мусіяка Н. І. Розвиток творчого мислення як особистісної детермінанти навчальних досягнень молодших школярів. Проблели сучасної психологї: Збірник наукових праць Кал'янець-Подільського національного університету ілені Івана Огієнка, Інституту психологї ілені Г. С. Костюка НАПН України. Кам'янець-Подільський : Аксіома, 2018. Вип. 41. С. 205-217. DOI 10.32626/2227-6246. 2018-41.205-217.

Нова українська школа: порадник для вчителя / за заг. ред. Н. М. Бібік. Київ : ТОВ «Видавничий дім «Плеяди», 2017. 206 с.

Папуча М. В. Суб’єктність учіння як психологічна проблема. Психолого-педагогічні улови розвитку особистісної активності в освітньолу просторі: монографія / Ін-т психології ім. Г. С. Костюка АПН України. Київ : ДП «Інформаційно-аналітичне агентство», 2008. С. 344-370.

Практикум по возрастной психологии: учебн. пособие / Под ред. Л. А. Головей, Е. Ф. Рыбалко. Санкт-Петербург : Речь, 2002. 694 с.

Становлення особистості школярів з різними навчальними досягненнями в онтогенетичному просторі: монографія / за ред. М. Т. Дригус. Кіровоград : Імекс-ЛТД, 2013. 154 с.

Яворська-Вєтрова I. В. Перспективна рефлексія як механізм становлення особистісної ефективності учнів. Проблели сучасної психологї: Збірник наукових праць Кал'янець-Подільського національного університету ілені Івана Огієнка, Інституту психологї ілені Г. С. Костюка НАПН Украӥни. Кам'янець-Подільський : Аксіома, 2018. Вип. 41. С. 462-473. DOI 10.32626/2227-6246.201841.462-473.

Beetham, H., \& Sharpe, R. (2013). Rethinking Pedagogy for a Digital Age. Designing for 21st century learning. New York : Routledge. DOI 10.4324/9780203078952.

Doğan, U. (2015). Student Engagement, Academic Self-efficacy, and Academic Motivation as Predictors of Academic Performance. The Anthropologist, 20 (3), 553-561. DOI 10.1080/09720073.2015.118917 59.

Iniesta, A. J., López-López, J. A., Corbíl, R. G., Pérez, P. M., \& Costa, J. L. C. (2017). Differences in cognitive, motivational and contextual variables between under-achieving, normally-achieving, and over-achieving students: A mixed-effects analysis. Psicothema, 29 (4), 533-538. DOI 10.7334/psicothema2016.283.

Kaya, F., \& Oğurlu, Ü. (2015). The relationship among self-esteem, intelligence, and academic achievement Benlik sayg1sı, zekâ ve akademik başarı ilişkisi. International Journal of Human Sciences, 12, 951965. DOI 10.14687/ijhs.v12i1.3089. 
Lepp, A., Barkley, J. E., \& Karpinski, A. C. (2015). The relationship between cell phone use and academic performance in a sample of U. S. college students. SAGE Open, 5 (1), 1-9. DOI 10.1177/2158244015573169.

Meens, E. E. M., Bakx, A. W. E. A., Klimstra, T. A., \& Denissen, J. J. A. (2018). The association of identity and motivation with students' academic achievement in higher education. Learning and Individual Differences, 64, 54-70. DOI 10.1016/j.lindif.2018.04.006.

Motlagh, S. E, Amrai, K., Yazdani, M. J, Abderahim, H. A., \& Souri, H. (2011). The relationship between self-efficacy and academic achievement in high school students. Procedia Social and Behavioral Sciences, 15, 765-768. DOI 10.1016/j.sbspro.2011.03.180.

Salomon, A., \& Ben-David Kolikant, Y. (2016). High-school students' perceptions of the effects of non-academic usage of ICT on their academic achievements. Computers in Human Behavior, 64, 143-151. DOI 10.1016/j.chb.2016.06.024.

Steinmayr, R., Crede, J., McElvany, N., \& Wirthwein, L. (2016). Subjective well-being, test anxiety, academic achievement: Testing for reciprocal effects. Frontiers in Psychology, 6, Article ID 1994. DOI 10.3389/fpsyg.2015.01994.

\section{References}

Vashchenko, I. V., \& Onufriieva, L. A. (2018). Kontseptualni mezhi poniattia kopinh-stratehii osobystosti u psykholohii [Conceptual boundaries of the concept of coping strategies of personality in psychology]. S. D. Maksymenko, L. A. Onufriieva (Eds.). Problemy suchasnoi psykholohii - Problems of Modern Psychology: Collection of research papers of Kamianets-Podilskyi Ivan Ohienko National University, G.S. Kostiuk Institute of Psychology at the National Academy of Educational Sciences of Ukraine, 41, 228-239. Kamianets-Podilskyi : Aksioma [in Ukrainian]. DOI 10.32626/2227-6246.2018-41.228-239.

Dryhus, M. T. (2016). Problema osobystisnoi efektyvnosti u konteksti naukovoi spadshchyny H. S. Kostiuka [The issue of personal efficiency in the context of scientific heritage of G. S. Kostiuk]. S. D. Maksymenko, L. A. Onufriieva (Eds.). Problemy suchasnoi psykholohii - Problems of Modern Psychology: Collection of research papers of Kamianets-Podilskyi Ivan Ohienko National University, G. S. Kostiuk Institute of Psychology at the National Academy of Pedagogical Sciences of Ukraine, 33, 148-161. Kamianets-Podilskyi : Aksioma [in Ukrainian].

Kozub, Y. V. (2016). Spetsyfika stavlennia do navchannia u vstyhaiuchykh ta nevstyhaiuchykh studentiv z dominuvanniam riznykh vydiv motyvatsii dosiahnennia [Specifics of the high and low level academic progress students' attitude to the learning with domination of diffe- 
rent types of achievement motivation]. S. D. Maksymenko, L. A. Onufriieva (Eds.). Problemy suchasnoi psykholohii-Problems of Modern Psychology: Collection of research papers of Kamianets-Podilskyi Ivan Ohienko National University, G. S. Kostiuk Institute of Psychology at the National Academy of Pedagogical Sciences of Ukraine, 32, 218-234. Kamianets-Podilskyi : Aksioma [in Ukrainian].

Kondratenko, L. O. (2018). Problemy pervynnoi shkilnoi neuspishnosti v istorii vitchyznianoi psykholohii [Problems of primary poor progress at school in the history of Ukrainian psychology]. Extended abstract of Doctor's thesis. Kyiv : "Naukovyi svit» [in Ukrainian].

Kostiuk, H. S. (1989). Navchalno-vykhovnyi protses $i$ psykhichnyi rozvytok osobystosti [Educational process and mental development]. L. M. Prokoliienko (Eds.). Kyiv : Radianska shkola [in Ukrainian].

Maksymenko, S. D. (2008). Osobystist: prohnoz rozvytku i zhyttievyi shliakh [Personality: development forecast and life path]. Psykholohichne oposeredkuvannia pedahohichnykh vplyviv na rozvytok osobystisnoi aktyvnosti $v$ osvitnomu prostori - Psychological mediation of pedagogical influences on personal activity development at education, (pp. 4-35). Kyiv : DP «Informatsiino-analitychne ahentstvo» [in Ukrainian].

Musiiaka, N. I. (2018). Rozvytok tvorchoho myslennia yak osobystisnoi determinanty navchalnykh dosiahnen molodshykh shkoliariv [Development of creative thinking as a personal determinant of primary schoolchildren's educational achievements]. S. D. Maksymenko, L. A. Onufriieva (Eds.). Problemy suchasnoi psykholohii-Problems of Modern Psychology: Collection of research papers of Kamianets Podilskyi Ivan Ohienko National University, G. S. Kostiuk Institute of Psychology at the National Academy of Educational Sciences of Ukraine, 41, 205-217. Kamianets-Podilskyi : Aksioma [in Ukrainian]. DOI 10.32626/2227-6246.2018-41.205-217.

Sofii, N. Z., Onopriienko, O. V., Naida, Yu. M., Prystinska, M. S., \& Bolshakova, I. O. (2017). Nova ukrainska shkola: poradnyk dlia vchytelia [New Ukrainian School: teacher's guide]. Kyiv : TOV «Vydavnychyi dim «Pleiady» [in Ukrainian].

Papucha, M. V. (2008). Subiektnist uchinnia yak psykholohichna problema [Subjectivity of learning as a psychological problem]. Psykholohopedahohichni umovy rozvytku osobystisnoi aktyvnosti $v$ osvitnomu prostori - Psychological-pedagogical conditions of personal activity development at education, (pp. 344-370). Kyiv : DP «Informatsiinoanalitychne ahentstvo" [in Ukrainian].

Golovej, L. A., \& Rybalko, E. F. (Eds.) (2002). Praktikum po vozrastnoj psihologii [Tutorial on Age Psychology]. Sankt-Peterburg : Rech' [in Russian]. 
Ball, H. O., Dryhus, M. T., Musiiaka, N. I., Petrenko, I. V., \& YavorskaVietrova, I. V. (2013). Stanovlennia osobystosti shkoliariv z riznymy navchalnymy dosiahnenniamy $v$ ontohenetychnomu prostori [Personality formation of schoolchildren with different academic achievements in the ontogenetic space]. Dryhus, M. T. (Eds.). Kirovohrad : Imeks-LTD [in Ukrainian].

Yavorska-Vietrova, I. V. (2018). Perspektyvna refleksiia yak mekhanizm stanovlennia osobystisnoi efektyvnosti uchniv [The perspective reflection as a mechanism of pupils' personal efficiency formation]. S. D. Maksymenko, L. A. Onufriieva (Eds.). Problemy suchasnoi psykholohii - Problems of Modern Psychology: Collection of research papers of Kamianets-Podilskyi Ivan Ohienko National University, G. S. Kostiuk Institute of Psychology at the National Academy of Educational Sciences of Ukraine, 41, 462-473. Kamianets-Podilskyi : Aksioma [in Ukrainian]. DOI 10.32626/2227-6246.201841.462-473.

Beetham, H., \& Sharpe, R. (2013). Rethinking Pedagogy for a Digital Age. Designing for 21st century learning. New York : Routledge. DOI 10.4324/9780203078952.

Doğan, U. (2015). Student Engagement, Academic Self-efficacy, and Academic Motivation as Predictors of Academic Performance. The Anthropologist, 20 (3), 553-561. DOI 10.1080/09720073.2015.118917 59.

Iniesta, A. J., López-López, J. A., Corbíl, R. G., Pérez, P. M., \& Costa, J. L. C. (2017). Differences in cognitive, motivational and contextual variables between under-achieving, normally-achieving, and overachieving students: A mixed-effects analysis. Psicothema, 29 (4), 533-538. DOI 10.7334/psicothema2016.283.

Kaya, F., \& Oğurlu, Ü. (2015). The relationship among self-esteem, intelligence, and academic achievement Benlik sayg1sı, zekâ ve akademik başarı ilişkisi. International Journal of Human Sciences, 12, 951965. DOI 10.14687/ijhs.v12i1.3089.

Lepp, A., Barkley, J. E., \& Karpinski, A. C. (2015). The relationship between cell phone use and academic performance in a sample of U. S. college students. SAGE Open, 5 (1), 1-9. DOI 10.1177/2158244015573169.

Meens, E. E. M., Bakx, A. W. E. A., Klimstra, T. A., \& Denissen, J. J. A. (2018). The association of identity and motivation with students' academic achievement in higher education. Learning and Individual Differences, 64, 54-70. DOI 10.1016/j.lindif.2018.04.006.

Motlagh, S. E, Amrai, K., Yazdani, M. J, Abderahim, H. A., \& Souri, H. (2011). The relationship between self-efficacy and academic achievement in high school students. Procedia Social and Behavioral Sciences, 15, 765-768. DOI 10.1016/j.sbspro.2011.03.180. 
Salomon, A., \& Ben-David Kolikant, Y. (2016). High-school students' perceptions of the effects of non-academic usage of ICT on their academic achievements. Computers in Human Behavior, 64, 143-151. DOI 10.1016/j.chb.2016.06.024.

Steinmayr, R., Crede, J., McElvany, N., \& Wirthwein, L. (2016). Subjective well-being, test anxiety, academic achievement: Testing for reciprocal effects. Frontiers in Psychology, 6, Article ID 1994. DOI 10.3389/fpsyg.2015.01994.

\section{Мусіяка Наталія. Дослідження мікрогенези детермінантного впли- ву фрустрації потреби досягнення успіху в школярів із різними навчальними досягненнями}

\section{АНОТАЦІЯ}

У статті представлено результати експериментального дослідження фррустрації потреби досягнення успіху й особливостей ї̈ прояву як особистісної детермінанти навчальних досягнень у школярів початкової та основної школи. Здійснено порівняльний аналіз мікроґенези рівневої констеляції фрустрації потреби досягнення успіху в школярів на різних етапах навчання. Установлено як тотожність, так і різнополярність тенденцій перебігу фрустрації у групах школярів із різним рівнем навчальних досягнень. Констатовано у відмінно встигаючих $і$ посередньо встигаючих школярів початкової школи ознаки певної дестабілізації особистісного статусу молодшого школяра, про що свідчить значне зростання фрустрації потреби досягнення успіху, $і є$ віддзеркаленням тих труднощів, які супроводжують процес суб'єктного включення частини школярів цих груп до прочесу учіння. Зафіксовано на мікрорівні у слабко встигаючих молодших школярів протилежну тенденцію - домінування нормального рівня, що є індикатором блокування особистісних потенцій щодо потреби досягнення успіху. Експериментально встановлено, що адаптивний період учнів п'ятого класу до навчання в основній школі має чіткі ознаки деструкції фрустрації потреби досягнення успіху в школярів із низьким рівнем навчальних досягнень. Зафіксовано становлення несприятливого психологічного тла з констеляцією чинників, що заважають розкриттю особистісних потенцій у досягненні успіху в процесі навчальної діяльності, становленню продуктивної суб'єктності слабко встигаючих п'ятикласників. 3'ясовано наявність у архітектоніці фрустрації потреби досягнення успіху мікрогенетичних тенденцій, що репрезентують детермінацію навчальних досягнень школяра в онтогенетичному вимірі. Установлені 
особливості фрустрації потреби досягнення успіху та ії деструкції вимагають розробки системи корекційно-розвивальних впливів із метою нівелювання деструктивного стану фрустрації та забезпечення продуктивного психологічного супроводу особистісного розвитку школяра в освітньому середовищі.

Ключові слова: ґенеза, мікроґенеза, навчальні досягнення, особистісна детермінанта, особистість школяра, потреба досягнення успіху, фрустрація.

\section{Мусияка Наталия. Исследование микрогенезиса детерминантного влияния фрустрации потребности достижения успеха у школьников с разным уровнем учебных достижений}

\section{АННОТАЦИЯ}

В статье представлены результаты экспериментального исследования фрустрации потребности достижения успеха и особенностей ее проявления как личностной детерминанты учебных достижений у школьников начальной и основной школы. Осуществлен сравнительный анализ микрогенезиса уровневой констелляции фрустрации потребности достижения успеха на различных этапах обучения. Установлено как тождество, так и разнополярность тенденций фрустрации в группах школьников с разным уровнем учебных достижений. Констатировано у младших школьников с высоким и средним уровнем учебных достижений признаки определенной дестабилизации личностного статуса младшего школьника, о чем свидетельствует значительный рост фрустрации потребности достижения успеха, что является отражением тех трудностей, которые сопровождают процесс субъектного включения части школьников этих групп в процесс учения. Зафиксировано на микроуровне у школьников с низким уровнем учебных достижений противоположную тенденцию - доминирование нормального уровня, что является индикатором блокировки личностных потенций потребности достижения успеха. Экспериментально установлено, что адаптивный период учащихся пятого классак обучению в основной школе имеет четкие признаки деструкции фрустрации потребности достижения успеха у школьников с низким уровнем учебных достижений. Зафиксировано становление неблагоприятного психологического фона с констелляцией факторов, блокирующих раскрытие личностных потенций в достижении успеха в процессе учебной деятельности, развитии продуктивной субъектности пятикласс- 
ников с низким уровнем учебных достижений. Установлено наличие в архитектонике фрустрации потребности достижения успеха микрогенетических тенденций, которые репрезентируют детерминацию учебных достижений школьников в онтогенетическом измерении. Установленные особенности фрустрации потребности достижения успеха и ее деструкции требуют разработки системы коррекционноразвивающих воздействий с иелью нивелирования фрустрации и обеспечения продуктивного психологического сопровождения личностного развития школьника в образовательной среде.

Ключевые слова: генезис, микрогенезис, учебные достижения, личностная детерминанта, личность школьника, потребность достижения успеха, фрустрация. 